world market would be much less costly. So if this agreement goes through, it would tend to undercut India's breeder reactor and reprocessing establishments," says von Hippel.

Many in the Indian nuclear establishment are also concerned at Singh's promise to accept the same restrictions as the five official nuclear weapons states. These include separating civilian nuclear facilities from military ones, allowing the International Atomic Energy Agency to inspect its civilian facilities, and maintaining a unilateral moratorium on nuclear testing.

Segregation of civilian and nuclear facilities would be expensive and impractical, says Padmanabha Krishnagopala Iyengar, former chairman of the Atomic Energy Commission and a key scientist in India's weapons development. He points out that at present both kinds of research are usually done at the same laboratories. "Nobody works full time in our weapons programme," he told Nature. "The moment we compartmentalize, our research and development will be crippled and creativity will end.'

Segregation could leave the entire nuclear programme in a mess, agrees Annaswamy Narayana Prasad, former director of the Bhabha Atomic Research Center in Mumbai. Given the small scale of military activities, dedicating facilities for a single purpose is neither practical nor cost effective, he says.

\section{U-turn required}

Younger scientists in India's nuclear establishment are more open to the separation of civil and military facilities. "Those who oppose it belong to an older generation with a closed mind-set," says one reactor designer at the Bhabha research centre, who asked not to be named. "The responsibility for running the nuclear programme is now on new shoulders and the present reality calls for a U-turn. Segregation is better than camouflaging."

But if nuclear cooperation means that India will find it cheaper to buy reactors from abroad, this would be a heavy blow for India's nuclear establishment. "India has been outside the nuclear club for some time, and has had to rely on endogenous resources," says Ziad Haider of the Henry L. Stimson Center, a Washington-based security think-tank. "These scientists now see their programme opened to international supervision, and becoming reliant on US technology," he says.

Iyengar agrees: "I think the Indo-US deal, if implemented, would tie our hands. All the self-reliance so relentlessly built over the years against heavy odds will go down the drain."

Declan Butler and K. S. Jayaraman, New Delhi

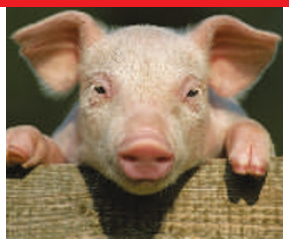

DISEASE KILLS

FARMERS IN CHINA

Outbreak sparks fears as authorities scramble for diagnosis.

www.nature.com/news

\title{
Sighting of 'extinct' bird may have been a case of mistaken identity
}

It was touted as the conservation discovery of a lifetime - an ivory-billed woodpecker, a bird long thought to be extinct, spotted in the Arkansas swamps. But now the finding is being called into question, which could cast doubt on several prominent US conservation measures.

In April, biologists and bird-lovers were thrilled by a videotape, reported in Science by ornithologist John Fitzpatrick of Cornell University in Ithaca, New York, of what looked to be an ivory-billed woodpecker (Campephilus principalis).

The species hadn't been confirmed in the United States since 1944, although there had been rare sightings in Cuba. The bird gradually vanished as its dense forest habitat was chopped down, making it a symbol of lost heritage.

So leading US officials, including the secretaries of the interior and agriculture, jumped at the chance to announce the bird's apparent rediscovery. They re-routed $\$ 10$ million from other conservation measures to pay for efforts to save the bird's vanishing habitat. These changes came swiftly, even though some in the Bush administration and Congress have been working to reduce species protections under the US Endangered Species Act.

But the investment may be premature, a new study suggests. A team of ornithologists led by Richard Prum of Yale University in New Haven, Connecticut, plans to report what it thinks is a case of mistaken identity. The bird described in Science, the group says, is not an ivory-billed woodpecker after all, but a non-endangered relative, the pileated woodpecker (Dryocopus pileatus).

Prum's team includes the leading US authority on ivory-billed woodpeckers, Jerome Jackson of Florida Gulf Coast University in Fort Myers, who for decades has been unable to document a sighting. "I have serious questions about the Science report," Jackson told Nature in May.

Prum and his colleagues scrutinized the Cornell team's video, and believe that the bird's size and white markings suggest that it could be a pileated woodpecker, rather than an ivory-billed woodpecker. The Cornell team had considered this possibility and discounted it.

Prum declined to discuss details of his manuscript until it is published in PLoS Biology. The third author of the paper is Mark Robbins, an ornithologist at the University of Kansas in Lawrence.

Fitzpatrick and other co-authors of the Science paper also declined to comment. $P L O S$ Biology plans to publish a response from the Cornell team, and a response to that from Prum's group. All three papers are expected to go online within a month.

Despite the challenge to the sighting, conservationists plan to meet in Little Rock on 2 August to discuss how to save the woodpecker's home forests. Rex Dalton

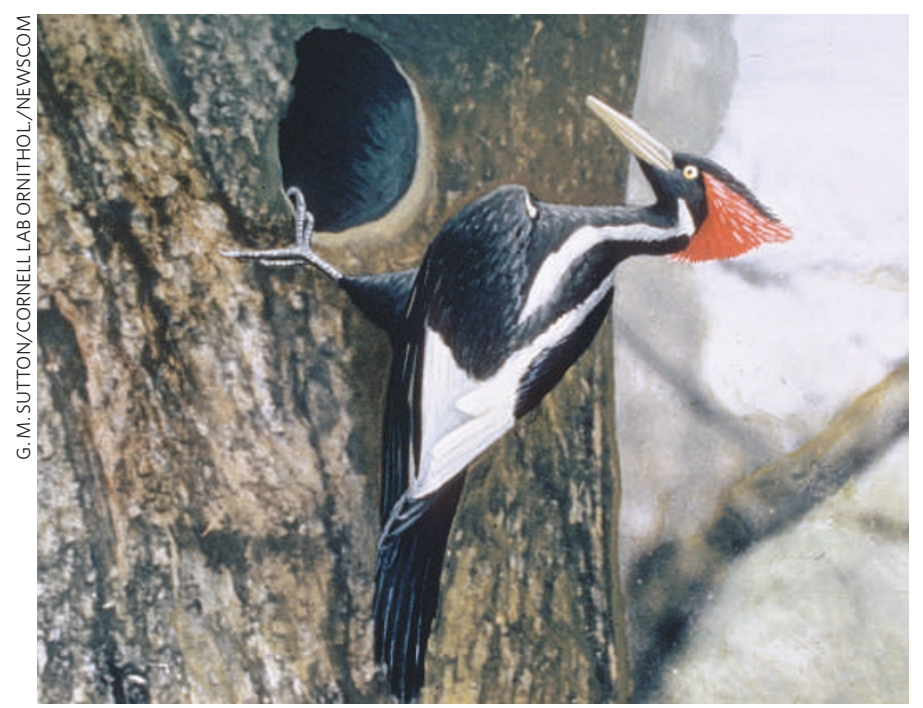

Down the pecking order: a sighting of the ivory-billed woodpecker, thought to have been extinct, may instead have been a non-endangered relative. 